\title{
International Metastatic Renal Cell Carcinoma Database Consortium Criteria
}

National Cancer Institute

\section{Source}

National Cancer Institute. International Metastatic Renal Cell Carcinoma Database

Consortium Criteria. NCI Thesaurus. Code C155843.

A validated risk prediction tool for patients with metastatic renal cell carcinoma (mRCC) receiving first-line targeted therapy. The model considers: Karnofsky performance status less than $80 \%$, time from diagnosis to first-line targeted therapy less than 1 year, hemoglobin concentration less than lower limit of normal, neutrophil count greater than upper limit of normal, platelet count greater than upper limit of normal, and serum calcium concentration greater than upper limit of normal. 